continues to expand at its present rate, Toshkov's pointers will be considered of value in the new historiography on agrarianism for many years to come.

\author{
Wim van Meurs \\ Research Institute for Culture \& History \\ Radboud University Nijmegen \\ Erasmusplein I, 6525 HT Nijmegen, The Netherlands \\ E-mail: w.v.meurs@let.ru.nl \\ doi:10.1017/S0020859020000437
}

Pagis, Julie. May '68. Shaping Political Generations. [Protest and Social Movements.] Amsterdam University Press, Amsterdam 20I8. 320 pp. Ill. $€ 105.00$

This volume reinforces the notion that the paramount French export in history has been the concept of revolution. The Great Revolution established a new calendar which created a Year One on the foundation of the First Republic in 1793 . Pagis argues that for certain individuals the events of May I 968 were their Year One, a conscious break with the past that provided new possibilities for activists. Inspired by what Pierre Bourdieu termed "the critical moment" or the "shared foundational event" (p. 2 I I) of 1968, in the I970s Pagis's parents resigned from their stable government jobs to return to the land as peasants. Their daughter became a political sociologist through meritocratic French Republican education.

Pagis's study focuses on "the family transmission of these [1968] events" (p. 28). Her perspective explores political and generational causes and consequences of participation in movements of the Sixties. Largely through interviews, she investigates hundreds of dedicated militants, disillusioned former activists, and their children, all of whom - in sharp contrast to Hervé Hamon's and Patrick Rotman's best-selling, similarly-titled but much less nuanced, Génération (1988) - never gained national reputations. Her biographical approach confirms that "it is impossible to understand what activism produces without also simultaneously studying what produces activism” (p. I 20).

Her excellent research turns up some surprising information. Forty per cent of her sample of May militants were educated by parents who were practicing Christians, usually Catholics. Their children became sympathetic to a humanist critique of capitalism and adopted varieties of Third-Worldism during the anti-Algerian and anti-Vietnam war movements. Less surprising is the over-representation in her pool of activist Jews (seventeen per cent) who were both Communist and Jewish and thus often members of doubly contested, if not persecuted, minorities. First-generation intellectuals from a working-class or peasant background often felt a certain "social illegitimacy" (p. 65), at least in the eyes of their more affluent classmates. Many ultimately became interested in Bourdieu's critical sociology and the study of social sciences in general.

During the 1968 crisis of "authority relations" (p. 78) that undermined traditional religion, morality, and education, some young men and even more women viewed themselves as "reborn" intellectually and emotionally. The ' 68 events destabilized the trajectories of these individuals who subsequently joined new social and friendship networks. The most radical wanted to disrupt social reproduction, and many came to reject the traditional family 
and contemporary consumerism. Communal living (broadly defined) became widespread, especially among students. A significant few managed to survive without salaried labor, deliberately representing the "downward mobility" (p. I30) of some '68 participants. Intentional "social migrants" (p. I49) from the middle to the working classes known as établis interpreted the "transgressions of class boundaries" (p. I39) in a sacrificial and "selfpurify[ing]" (p. I42) manner and wished to purge themselves of their alleged bourgeois desires. Charismatic male "prophetic figures", such as Robert Linhart or Daniel Cohn-Bendit, embodied this "open realm of possibilities" and "the existence of alternatives" (p. IIs).

The author is familiar with English-language sociological literature on the Sixties but possesses less knowledge of Anglo-American historiography. This is unfortunate since a reading of Arthur Marwick, The Sixties: Cultural Revolution in Britain, France, Italy and the United States, c. 1958-c.1974, might have given her analysis of '68 veterans during the decades following May a broader vision that would have emphasized the large social and cultural changes of what Marwick called the "long Sixties". Thus, not all the "social movements of the 6os" went into "sharp decline" (p. i i ) from the late I970s. On the contrary, feminism, ecology, and multiculturalism showed remarkable persistence, if not expansion. In this sense, the Sixties constituted a cultural revolution that avoided or changed, at least to some extent, what Pagis terms "social reproduction". In other words, important elements of what the author labels the "counterculture" became accepted culture. As one of her interviewees, Françoise, states: "Political discourse took hold of May '68 to make it into something political. But May '68 was in fact something else, which was never said, which can't be said. Everyone found their own personal stories in it, their own remedies and their way of living, of being" (p. 236).

The author confronts indirectly the problem of the confusion between memory and history. She is aware that what the participants remembered in interviews forty years after the events as reasons for participating in May '68 might not have reflected their motivations at the time. Three quarters of the interviewees of both sexes declared that they were now feminists; whereas, less than one quarter said they are Marxists. Nonetheless, in '68, Marxism was much more prominent than feminism. Former participants may recall their feminist inspirations more vividly since feminism in France has survived more successfully than Marxism. As Pagis remarks, collective identity lasts only on the condition that militant memory is transmitted.

The author emphasizes that small differences of age - what she calls the numerous microunits of generation '68 - had important effects on how individuals experienced the events and were subsequently influenced by them. Older militants who had actively opposed the Algerian War were not as deeply affected by the ' 68 events as the more numerous younger participants who had less political experience. May "gave meaning” (p. I Io) to the lives of the latter. Students who were young and single during the events were most likely to identify themselves as members of the "'68 Generation" (p. 21 5). Female interviewees saw '68 as shaping their lives; whereas men claimed to have shaped '68. Women ultimately suffered more than men from new lifestyles since these provoked breaks with their families. Years after May, a good number of female participants became depressed. Thus, Pagis's gendered perspective can be useful to better understand the construction of different political generations.

Some of her interviewees during 1968 were unionized workers who were affected rather minimally by the events. Several others were non-union workers who enjoyed factory occupations as a pleasant and amusing break from the routine. Even if a number found that the 
events provided means "to transgress the symbolic barriers habitually erected between the social actors" (p. I I I), Pagis may overemphasize this "breakdown in social barriers between the worlds of workers, students and farmers” (p. 136) since workers often ignored or rejected student activists' attempted intrusions into their strikes. Furthermore, farmers were largely indifferent or hostile to urban strike movements. The inability of the sacrificial and missionary établis, who were usually Maoists, to create significant political or social change was evidence of the difficulty of overcoming class barriers.

Engagement or reconversion of former militants into academic research or journalism in publications such as Libération often eased the transition of those who had become disillusioned with their faith in the "revolutionary masses". The new professions promoted a sounder but still sympathetic view of the disadvantaged. At the same time, the return to the university or commitment to an intellectual profession often meant escaping the downward mobility and marginalization that were sometimes consequences - and, as the author makes clear, not causes - of post-May activism. Other former militants were unable to make this transition to a more conventional existence and suffered depression, alcoholism, and even suicide.

The author's ' $68 \mathrm{ers}$ were successful in transferring their generally leftist politics and countercultural practices to their children, even if the second generation was less militant than their parents. Only one fifth of their offspring became activists. The children experienced what Pagis labels "dissonant socialisations" and felt trapped between their parents' "countercultural" socialization and the more orthodox one promoted by the state and society.

Even though this English translation from the French contains too many grammatical, formatting, and spelling errors, these faults pale in comparison to the author's formidable research not only on the actors' ability to shape events, but also into the consequences of the events for the actors. Her portrait of French '68ers offers a judicious alternative to both hagiography and denigration.

Michael Seidman

History Department, University of North Carolina Wilmington, $\mathrm{NC}_{2} 8_{403}$, United States E-mail: seidmanm@uncw.edu doi:10.1017/S0020859020000449

\section{Toth, Stephen A. Mettray. A History of France's Most Venerated Carceral Institution. Cornell University Press, Ithaca (NY) [etc.] 2019. xii, 263 pp. Ill. \$43.95. (E-book: \$2 I.99.)}

This monograph by Stephen A. Toth, Associate Professor of Modern European History at Arizona State University, is dedicated to the history of the Mettray penal and agricultural colony. Founded in I 840 by Frédéric-Auguste Demetz, this institution aimed to socially rehabilitate young delinquents by subjecting them to agricultural work in order to promote their moral regeneration. An ancestor to the bagnes d'enfants that the journalist Henri Danjou denounced in 1932, the colony of Mettray has become famous thanks in particular to one of its most famous residents, Jean Genet, who wrote about it in his book Miracle de la Rose, and to the chapter devoted to Mettray by Michel Foucault in his book Surveiller et 